\title{
Identity Dynamics and Conflict in Collaborative Processes: The Case of Participatory Management of Protected Areas in Benin
}

\author{
Latifou Idrissou ${ }^{1,2}$, Noelle Aarts ${ }^{3}$, Cees Leeuwis ${ }^{4}$, Annemarie Van Paassen ${ }^{4}$ \\ ${ }^{1}$ International Institute for Tropical Agriculture (IITA), Ibadan, Nigeria \\ ${ }^{2}$ Faculty of Agronomy (FA/UP), Parakou, Republic of Benin \\ ${ }^{3}$ Strategic Communication Group, Wageningen University, Wageningen, Netherlands \\ ${ }^{4}$ Knowledge, Technology and Innovation Group, Wageningen University, Wageningen, Netherlands \\ Email: L.idrissou@cgiar.org, latifou.idrissou@fa-up.bj
}

How to cite this paper: Idrissou, L., Aarts, N., Leeuwis, C. and Van Paassen, A. (2016) Identity Dynamics and Conflict in Collaborative Processes: The Case of Participatory Management of Protected Areas in Benin. Journal of Environmental Protection, 7, 1981-2008.

http://dx.doi.org/10.4236/jep.2016.713154

Received: October 22, 2016

Accepted: December 11, 2016

Published: December 14, 2016

Copyright $\odot 2016$ by authors and Scientific Research Publishing Inc. This work is licensed under the Creative Commons Attribution International License (CC BY 4.0).

http://creativecommons.org/licenses/by/4.0/ (c) (i) Open Access

\section{Abstract}

The research reported in this paper investigated the role of identity construction in the emergence and escalation of conflict in the participatory management of protected areas in Benin. The study shows that social identity salience was dynamic and played an important role in the emergence and escalation of conflict in the studied cases. Conflicts emerged when identities became salient as a result of the stakeholders' framing of contextual factors as a threat to their identity. The conflicts escalated when decisions and actions undertaken in the management process were framed as top-down and as posing a threat to the identities of the stakeholders. We conclude that, although the government in the management of the protected areas introduced participation, unilateral decisions taken about the way the conflicts should be managed caused disappointment and distrust, and thus led to a greater distance between the parties involved and to conflict escalation.

\section{Keywords}

Participation, Social Identity, Conflict, Protected Areas, Benin

\section{Introduction}

Conflicts over natural resources such as land, water, and forests are inevitable, ubiquitous, and will exist for the foreseeable future [1] [2] [3] [4]. However, there is still confusion about whether or not conflicts are desirable in natural resources management [5]. On the one hand, conflicts over natural resources are considered as negative phenomena because of their complexity and the unpredictability of their impact on these 
resources, and on both the interests and the well-being of the people involved [5] [6]. Indeed, conflicts over resources can sometimes become harsh and result in violence, resource degradation, the undermining of livelihoods, and uprooting of communities [2]. On the other hand, conflicts over natural resources have been seen as an important leverage for environment management by ensuring that the voices of the different stakeholders are heard and that new social demands are responded [5].

Although conflict has many negative impacts, many studies have recognized the value of conflict as a catalyst for positive social change [1]. Conflict can be extremely valuable as the motor of progress or the mechanism by which injustice is removed [7].

Nowadays, the aim is not to avoid conflicts, but to make it possible for conflicts to evolve without violence, death, suffering and misery [7]. In that sense, Desloges and Gauthier [8] have pointed out that:

As such, conflictual situations are neither positive nor negative but they can be used in a constructive or destructive way. Many authors consider that conflicts are crucial not only for social change but also for the continuous creation of society by society itself. Therefore, conflict should not be viewed only as a dysfunctional relationship between individuals and communities that should be avoided at all cost but, also, as an opportunity for constructive change and growth.

Thus, if managed adequately, conflict over natural resources can yield positive outcomes such as reaching agreements and improving resources management (e.g., via better collaboration), whereas, if addressed badly, it may carry negative overtones such as bad relationships, destruction of resources, and violence [9]. With this mix of the impacts of conflicts, we still need to understand when and how conflicts over resources become cooperative and beneficial or destructive in the participatory management of natural resources.

Participatory management of natural resources was introduced in Benin during the early 1990s when the top-down approach used in the management of these resources proved unsuccessful in terms of conservation. In 1993, the forest department decided to involve local communities in the management of its protected areas in order to cope with their continuous degradation caused by illegal logging, poaching, overgrazing, and occupation for agriculture. After a few years of relatively successful collaborative management, various conflicts emerged between the forest department representatives and the local communities [10]-[15]. Negotiations undertaken between the stakeholders even escalated some of these conflicts (see [13] [14] [15]). In this paper, we presented a study that investigated three cases of conflict in the participatory management of natural resources in Benin.

Different social groups, who often have clearly diverging agendas, values, perspectives, and goals, are involved in participatory natural resources management on the assumption that they share power in decision making about, and implementation and evaluation of, the management of these resources [16] [17]. In the natural resources management literature, conflicts that emerge are often seen as a consequence of the incompatibility of interests, values, roles, responsibilities, or access and property rights to 
the same territory or resources between at least two interdependent groups (see [4] [9] [18] [19]. These conflicts often give rise to confrontations between local communities and government officials (see [18] [19]), between different stakeholder groups in the same community (see [1]), between different ethnic groups (see [20]), or between local communities and private companies. Whereas natural resources have economic, cultural, and historical importance for the local communities, government officials often favour conservation while promoting alternatively income-generating activities as sources of livelihood for local communities, and private companies are driven by purely economic goals.

In the conflict literature, however, social identity construction is considered to be at the core of conflict emergence in intergroup negotiation such as participatory management, which is commonly conceptualized as a process centred around the dual concerns (and perspectives) of self and other [16]. Many of the core concepts in the negotiation literature relate to the issue of social identity because the primary problem in negotiation is the existence of social groups whose members are exposed to ingroup favouritism and out group pressures [16] [21]. Many conflicts are thus attributed to differences in social identity [22] [23] [24] [25] [26]. However, the natural resources management literature pays little attention to the influence of the social identity of groups involved in conflict. The focus is often on tangible and especially economic interests and clashes, but group conflict can also revolve around symbolic resources, such as social status, values, and identity [27] [28] [29].

People define their sense of self in social contexts by referring to their group membership, which impacts on their behaviour [30] [31]. According to Tajfel et al. [32], the mere fact of social categorization is an inevitable source of conflict and tension [16] [33]. Social identity theory focuses on prejudices, discrimination, and conditions that promote different types of intergroup behaviour such as conflict, cooperation, social change, and social stasis [24]. It is used to analyse intergroup interactions either to predict conflict emergence or to manage them better in negotiation processes [16] [25]. Thus, in this study we used the social identity approach to understand the role of identity construction in conflict relating to participatory natural resources management. We investigated three such conflicts in Benin to deepen our understanding of the role that social identity played in the stakeholders' interactions and the extent to which it contributed to the emergence and escalation of the conflicts.

\section{Social Identity Approach}

The concept of social identity was first introduced by Tajfel who defined it as "the individual's knowledge that he belongs to certain social groups together with some emotional and value significance to him of this group membership" [35], p. 292. Social identity theory thus explains how self is conceptualized in intergroup contexts, which means how people create and define their own place in society through a system of self categorizations [36]. According to social identity theory, people tend to categorize themselves and others into various social categories such as organizational membership, religious affiliation, gender, age group, locality, etc. [37]. 
Social identity plays an important role in the connection that people feel with groups; in their wish to distinguish themselves from others; and ingroup behaviour such as the more positive treatment of members of one's own group-ingroup-favouring-as opposed to members of other groups-stereotyping and prejudice [38] [39]. It provides a basis for perceptual, attitudinal, and behavioural effects of group membership [40]. It appears that groups react differently according to the social context. Depending on the social context, different identities are made salient by groups. Groups make salient a type of social identity in response to a situational activation of an identity at a particular level to fit with the social field [30] [36].

\section{Social Identity Salience and Conflict Emergence in Negotiation}

Social identity salience is seen as the main predictor of conflict in intergroup interaction [16] [25] [30] [33] [34]. A group's salient identity can be defined as the most important identity of that group and with which people belonging to the group psychologically identify themselves within that context [25] [30] [34]. For example, people with a salient ethnic identity are more prejudiced and show more readiness for conflict behaviour towards other ethnic groups [25] [41]. Thus, a salient social identity triggers actions against out group members and leads to conflict [25].

Scholars involved in social identity research have always been concerned about what makes a particular social identity salient in a situation and thus activates conflict. Several predictors of early warning of conflict centred on social identity have been identified by Korostelina [25]. As a particular identity activation or salience is a function of the interaction between the characteristics of the group and the situation [30], conflict emergence is related to the characteristics, forms, types, and nature of the salient social identity, and intergroup relations (see [24] [25]). We discuss below those relevant in understanding conflict emergence in natural resources management.

One of the maingroup features that play a significant role ingroup behaviour in interaction is ingroup primacy, which refers to the feeling of supremacy of group goals and values over individual goals and values [24]. Several components form the primacy of an ingroup [25]: 1) predominance of ingroup aims over individual aims; 2) the readiness to forget all internal ingroup conflicts in situations of threat to the ingroup; and 3) the readiness to unite against an out group. This characteristic of group identity can increase or decrease the influence of identity salience on the conflict behaviour of the members of the ingroup. Thus, in participatory natural resources management, a group may enter into conflict with other groups just because the interests of some ingroup members are threatened and not those of the group as a whole; this results in unstable relationships.

The mode of identity meaning or social identity content determines the type of identity conflict that emerges [25] [26]. The meaning of social identity is usually multimodal and contains several components such as ingroup traditions and values (culture), ingroup language, characteristics of ingroup members, ingroup interests, history of ingroup, ideology of ingroup, outgroup image, etc. The dominance of a component in the 
social identity of a group in a context leads to conflict based on the difference in that component compared with outgroups [26]. The dominance of outgroup image, for example, may lead to conflict about difference in image arising from ingroup and outgroup comparison. As participatory natural resources management involves stakeholder groups with different perspectives, objectives, and interests vis-à-vis these resources, conflict among them may emerge due to the dominance of some of these differences in interaction.

States of intergroup relations such as intergroup prejudice and outgroup threat also lead to conflict. Prejudice is often defined as a negative attitude or as an antipathy based on faulty and inflexible generalization directed towards individuals as members of a group or to the group as a whole [24]. Thus, outgroup threats increase intergroup prejudice and lead to more hostility towards the outgroup. When threatened, group members perceive members of other groups as more homogenous with one another, and develop more extreme positions and less tolerance towards them [24]. Group members feel more threatened when the threat is directed at their social identity by an outgroup [39]. In participatory natural resources management, intergroup prejudice may often be experienced as each group may evaluate positively its members and negatively outgroup members when they feel the identity of their ingroup threatened by the outgroup.

According to Korostelina [25], the intensity of the perceived prejudice or threat to the social identity of the ingroup is higher when the social identity is acquired by ingroup members than when it is ascribed to them. People who acquire a social identity are more committed to ingroup beliefs, values, and norms than people with ascribed identities. Thus, in participatory natural resources management, conflicts are more likely to emerge when the perception of prejudice or threat concerns an acquired rather than an ascribed social identity.

In summary, identity conflict may emerge in participatory natural resources management when the social identities of the stakeholder groups become salient due to intergroup primacy and the development of intergroup prejudice or the feeling of threat from an outgroup. The type of identity conflict that emerges depends on the mode of identity meaning at the basis of intergroup comparison and the intensity of its influence on the nature of the identity (acquired or ascribed) under threat. Identity salience could thus be a major concern in participatory natural resources management.

\section{Dynamic of Social Identity Salience in Negotiation}

Many approaches to reducing intergroup identity conflicts focus on the need to increase the quantity and quality of intergroup contact in order to decrease the salience of groups' identities [16] [42] [43]. However, different views have been developed on how intergroup contact should be achieved to deal with social identity salience in conflict prevention and conflict management in negotiation processes. In early applications of social identity principles, scholars argued that the most appropriate method to avoid or resolve social conflict was to apply procedures that served to reduce the social identity 
salience of groups involved in interaction or conflict [16]. They suggested the decategorized contact model, which encouraged individual representations of (potentially) conflicting group members in intergroup contacts because individualized views would be inconsistent with the stereotypic beliefs of the group that lead to or perpetuate conflict. Decategorization seeks to reduce ingroup and outgroup bias that leads to conflict by moving (former) ingroup members, as individuals rather than as part of a group, away from the self towards outgroup members [16] [43]. Other scholars proposed the common ingroup identity model and argued that a superior strategy was rather recategorization, which 'transforms members' cognitive representations... from 'us' and 'them' to a more inclusive 'we"” ([44]: p. 232). Recategorization seeks to alter the categorizations used by replacing the subordinate "us" and "them" to create a superordinate "we" categorization [43].

Several criticisms have been made of the decategorization and recategorization models (see Ashforth and Mael, 1989; [16] [43] as both advocate violence to the social reality that they are supposed to address by seeking to break the existing social identities. The recategorization model even overlooks the power relations between the different groups in their willingness to impose a superordinate social identity on the parties in negotiation. Another limitation of both models is that they are based on the assumption that intergroup conflicts are bad and hence must be avoided at all cost, whereas conflict and co-operation are seen as two sides of the same coin that alternate to give structure, meaning, and direction to social life [16].

Some scholars then argued that the fact that parties were involved in negotiation presupposed that they all believed in the existence of a so-called win-win or integrative agreement that would satisfy the minimum requirements of both parties. Thus, negotiation usually happens because the parties involved acknowledge the existence of a shared superordinate identity [16]. Intergroup negotiation is then seen as revolving around counter-posed social identities defined at subgroup and superordinate levels. Researchers have recently argued that the best way to deal with intergroup negotiation is not to increase the salience of a social identity at the expense of subgroup identities but to acknowledge and allow the expression of both superordinate and subgroup identities [16] [37] [43]. This way of thinking is at the core of the dual-identity model of conflict management. This model seeks to reduce bias between subgroups who share a common superordinate identity in addition to considering themselves as members of separate groups [42] [43]. Figure 1 depicts the dual-identity, the decategorization, and the recategorization models, schematically.

The models for intergroup identity conflict management are presented as if, in a negotiation process, one model or another should be applied that may or may not fit the negotiation process. However, we posit that a negotiation process is dynamic and may reflect different models at different steps of the process. Thus, a negotiation process may start with one model and switch to another due to the salience of either the subgroup identity or a superordinate identity, or both subgroup and superordinate identities in interaction. So, rather than being considered as strictly distinct, these models 


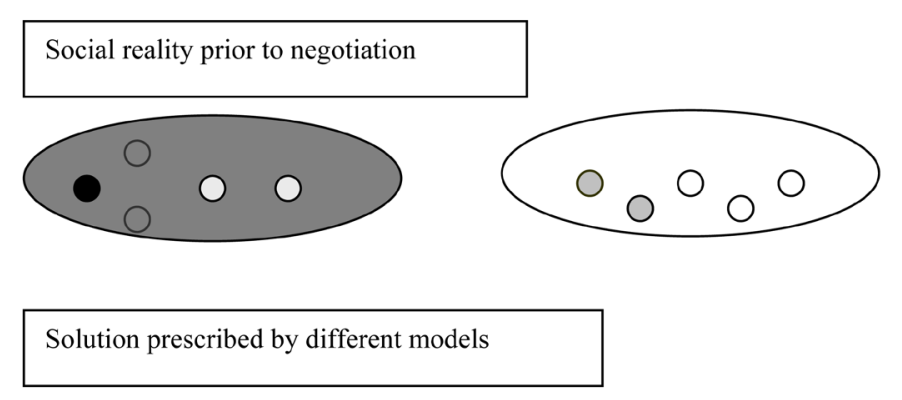

\section{Conflicting} intergroup relations

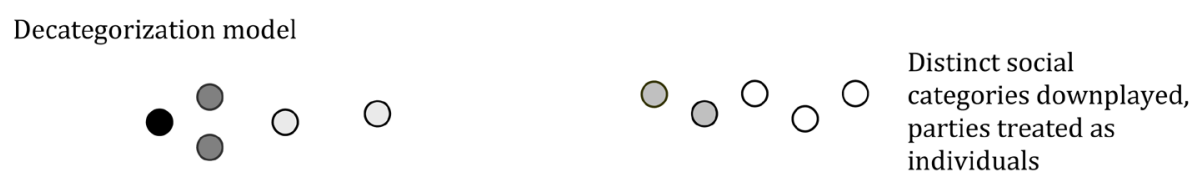

Recategorization model

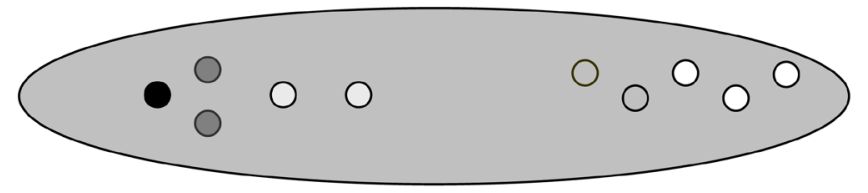

Distinct social categories downplayed, parties treated as members of common superordinate category

Dual-identity model

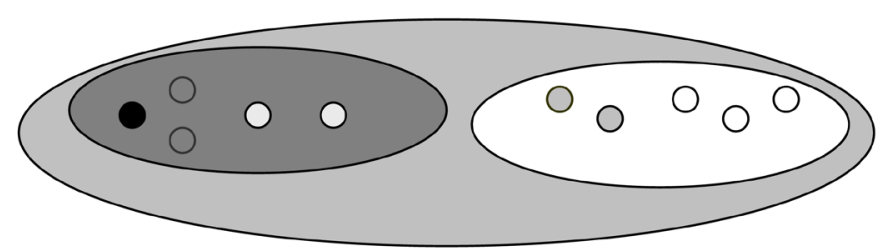

Distinct social categories recognized, but accommodated within a common superordinate category

Figure 1. Categories-based solutions to intergroup conflict (Haslam, 2001).

should be seen as interconnected interactional contexts within which a negotiation process may be going back and forth.

Participatory natural resources management involves different stakeholder categories with different identities. Thus, different identities may become salient in different contexts. In this study, we looked at how identities became salient and how their dynamic led to conflict in three case studies of participatory natural resources management in Benin.

\section{Cases Studied and Method}

This study investigated conflict emergence and escalation in the participatory management of three protected areas in Benin: the Agoua forest, the Ouémé Spérieur and N'dali (OSN) forests and the Pendjari National Park (PNP).

The Agoua forest is a protected area put under government protection in 1953. It is situated in the centre-west of Benin in the municipality of Bantè. When it was declared a protected area, the Agoua forest covered about 75,300 ha [45]. However, this forest was progressively occupied by local communities who created villages and farms in it. The forest's area had decreased to 68,848.43 in 2002 (PAMF, 2006). The forest depart- 
ment thus decided to restore it in 2002 under a five-year project, the Project for the Management of the Wari-Waro, Monts Kouffè and Agoua Forest Massifs (PAMF: Projet d'Aménagement des Massifs Forestiers d'Agoua, des Monts Kouffè et de Wari-Waro). The aim of the project was the participatory restoration of the forest through the establishment and implementation of the participatory management plan for the Agoua forest (PAMF, 2006).

The OSN forests are formed by the Ouémé Supérieur forest, declared a protected area in 1952, and the N'dali forest, declared protected in 1942. These forests cover respectively 193,406 ha and 4721 ha, are located in the north of Benin, and shared by the municipalities of Tchaourou, Djougou, and N'dali. These forests are managed together as they are close, have similar ecosystems, and face the same anthropogenic pressure [46]. These forests were solely managed by the forest department from 1952 until the early 1990s when a participatory approach was introduced in the management of Benin's protected areas. The participatory approach-community-based natural resources management (CBNRM) - was introduced in the management of the OSN forests by the Natural Resources Management (NRM) project (Projet de Gestion des Ressources Naturelles) in 1993, which established the participatory management plan for these forests. The implementation of the plan was started by the local communities and later supported by the Forests and Adjacent Lands Management (FALM) programme (Programme de Gestion des Forêts et Terroirs Riverains). Local communities formed village associations for forest management (VAFM: Association Villageoise de Gestion des Forêts), which were involved in the management of these forests together with government officials.

The PNP was created by the colonial administration in 1954 and covers an area of 471,000 ha. It is located in north-western Benin and shared by the municipalities of Tanguiéta and Matéri. Like all Benin's protected areas, it had been managed by government officials using a top-down approach until 1993 when the participatory approach was introduced. Local communities have been involved in the management of the park through the village associations for wildlife management and eco-guards recruited by the park direction in the villages surrounding the park.

In each of these cases, data were collected through interviews, observations, and document consultation (see Table 1). Key informants in each stakeholder category were interviewed individually, and focus group discussions were organized to triangulate the information gathered through the individual interviews. Data were also collected through participation in meetings organized in the framework of the management of these protected areas and observations of the activities of the different stakeholders involved. The interviews and conversations were tape-recorded and tran-

Table 1. Interviews, focus group discussions, and meetings attended for each case.

\begin{tabular}{cccc}
\hline Cases & Individual interviews & Focus group discussions & Meetings attended \\
\hline Agoua forest & 39 & 06 & 02 \\
OSN forests & 33 & 09 & 03 \\
PNP & 31 & 07 & 05 \\
\hline
\end{tabular}


scribed. Documents such as project and study reports on the protected areas and the local communities were consulted to gather general information on the protected areas and the local communities, as well as events that occurred during the management of these protected areas and that have been documented.

The data gathered and processed were analysed using the interaction analysis method (see [47] [48]). Interaction analysis is an interdisciplinary method suitable for the empirical investigation of the interaction of people with each other and with objects in their environment [48]. Interaction analysis consists of describing people's behaviour in relation to those with whom they are doing interaction work in the construction of recognizable social scenes or events [47]. We used interaction analysis in this study to investigate activities such as talk and non-verbal interactions of stakeholders involved in the participatory management of protected areas in Benin to identify routines, practices, and problems, and the resources for their resolution [48]. Interaction analysis was used in multiple cases studied to identify interactional patterns in conflict emergence and escalation in protected area management in Benin (see [48]).

\section{Findings}

Because protected areas were created in Benin during colonial times, government officials managed them solely, and it was considered undesirable for local communities to be involved in their management [49]. This created tense relationships between the forest department and local communities who never accepted the way these protected areas were created and managed by the state. The local communities perceived that their lands and resources had been expropriated by the state and used any occasion to exploit these resources for their livelihood. At the same time, the forest department considered the local communities as a threat to the natural resources and put its efforts into keeping them as far as possible from the protected areas. The relationship between local communities and the forest department was characterized by conflicts that persisted for more than three decades, since the protected areas were created between 1940 and 1960 and lasted until participation was introduced in 1993.

The aim of the forest department was to foster sustainable management of forest resources under their care, but they had insufficient personnel to do so on their own. By introducing a participatory process, they intended to enlist the assistance of local communities in this endeavour [46] [50] [51]. The first challenge for the forest department at the beginning of the process was to reverse the negative images that they and the local communities had constructed of each other over time. In the participatory management processes implemented, the forest department, in conjunction with the representatives of the local communities, undertook to reconstruct each other's social identity through several actions and interventions during the establishment and implementation of the participatory management plans for the protected areas.

\subsection{The Establishment of the Participatory Management Plans for the Protected Areas}

Participatory management of the protected areas in Benin started with the establish- 
ment of their respective participatory management plans. In the three cases studied, establishment of the plan involved the forest department and the local communities. However, the process was facilitated by an NGO in the case of the OSN forests. The establishment of the plan began with several meetings involving both forest department representatives and local communities. They were organized to assess the problems of the protected areas and those of the local communities and raise awareness among the stakeholders about these issues. The way the resources of these areas should be managed and the roles and responsibilities of all the stakeholders were also decided and inscribed in the participatory management plan. These meetings were also meant to enable the local communities to become familiar with the forest department representatives in order to extinguish the fear of the forest rangers experienced by the local communities over the past decades of coercive management. The forest department also undertook to improve the livelihood of local communities by building socio-communitarian infrastructures and initiating and financing income-generating activities in the villages surrounding the protected areas. Local communities were also involved in the management of the protected areas through VAFM. In the case of the Agoua and OSN forests' participatory management, local communities had been assigned the task of carrying out reforestation activities and forest surveillance assisted by forest rangers (FRs). In the case of the PNP, the guards were recruited as staff of the park direction. The former forest rangers were progressively replaced by eco-guards recruited in the villages surrounding the park to carry out surveillance. The director of the park explained the recruitment of the local communities as personnel of the park direction, arguing:

...continuing to send the FRs, with whom the local communities had had a lot of trouble in the past even with gunshots, would mean that the park direction still wanted to pacify the region instead of collaborating with the local communities. (Source: Director of PNP, January 2010)

By changing the local communities' negative frames about forest department representatives, constructed from the time the protected areas were created until participation was introduced in 1993, the forest department hoped to enable better collaboration with these local communities. This intention of the forest department was highlighted in the utterances of its representatives interviewed in the three cases. The head of the forest department in the Borgou region said in this respect:

Contrary to the past, the forest department invited local communities to define what to do and work together. From the beginning, we have noticed local communities' interest in the participatory management of the OSN forests as they could approach the FRs without fear. It was clear that the forest department was a little bit frustrated as we had managed these forests alone for decades and we were powerful and feared. However, immediately this fear of local communities was reduced with the introduction of participatory management. (Source: Head of Borgou's forest department office, February 2009) 
These statements show that the main concern of the forest department at the beginning of the participatory process was to alter the categorization established during the coercive management period between the forest department representatives and the local communities. These statements also show that, according to the forest department, the actions that it undertook during the participatory management process to reverse this tendency yielded encouraging results as the local communities' fear of the FRs decreased.

The local communities also expressed their enthusiasm vis-à-vis these actions by the forest department, as illustrated in their statements below. The local communities in the Agoua forest restoration case praised the PAMF project in this respect:

At the start, we were happy with the PAMF as it built infrastructures in our villages and enabled many villagers to earn money by working with the restoration and hunting committees. We thanked the government for choosing our region for the implementation of this project. (Source: Focus group discussion with Bantè's farmers, March 2007)

The local communities involved in the management of the OSN forests also expressed their positive view of the forest department through their appreciation of the actions of the NRM project. Their representatives acknowledged it, arguing:

During the management of the forest by the NRM project, villagers were very enthusiastic as they were very often invited to meetings. Each month there were meetings to which we were invited together with the FRs and then we knew what was going on in the management of the forests. (Source: Focus group discussion with Bétérou VAFM board members, January 2009)

The interview excerpts above show that, although the forest department and local communities had considered each other as enemies for decades, they apparently managed to build positive frames of each other during the earlier phase of the participatory process. These utterances in particular highlight the fact that the change in these stakeholders' framing of each other was due to interactions at meetings, awareness raising campaigns, training, promotion of income-generating activities involving both stakeholder categories organized in the framework of the participatory management of the protected areas, and some concessions made to the local communities in terms of access to, and use of, some resources in the protected areas. A close look at these statements reveals that all these activities provided local communities with new roles, responsibilities, and resources that had been exclusively held and controlled by the forest department in the past. The forest department in all these cases presented itself as close to the local communities in contrast to the past when its representatives were feared by them.

The establishment phase of the participatory management plan shows the negotiation models adopted by the forest department. In each of these cases, the forest department opted for the creation of a superordinate identity involving the representatives of the forest department and local communities in the sustainable management of 
the protected areas, within which the participatory management plan represented the institutional framework. However, in the case of the Agoua and OSN forests, the identities of both stakeholders were acknowledged and the roles and responsibilities were shared on the basis of these in the participatory management plan, whereas, in the case of the PNP, the identities of the eco-guards and of the park direction were downplayed as the eco-guards were considered members of the staff of the park direction. Thus, the forest department opted for the dual-identity model in the cases of the Agoua and OSN forests and the recategorization model in the case of the PNP.

In all three cases, the establishment of the participatory management plans for the protected areas was followed by their implementation.

\subsection{The Implementation of the Participatory Management Plan and the Emergence of Conflicts}

The implementation of the participatory management plan consists of the management of the protected areas according to the rules established in the plan. In contrast to the establishment phase of the plan where the forest department and local communities built new relationships that brought them closer together, the implementation phase was characterized in the three cases studied by conflicts between these stakeholders. Although these conflicts arose in different contexts and were triggered by different reasons, they had several features in common.

\subsubsection{The Agoua Forest Case}

Although the forest department managed the protected areas coercively for decades until participation was introduced, local communities settled in the Agoua forest where they created villages and farms. The participatory management plan for Agoua forest thus divided the forest into four zones: the service zones for roads to access the villages in the forest, the agro-forestry zones dedicated to farming, and the protection and production zones-where no farmer was allowed to settle-dedicated to reforestation (PAMF, 2006). It was also decided in the plan that all the farmers scattered throughout the forest should move to the agro-forestry zone. The managers of the PAMF project and local communities' representatives agreed on the plan at the beginning of the project [13]. However, when the implementation phase was announced by the project in 2006, the local communities opposed it. The implementation of the plan presupposed that farmers who had their farms in the production and protection zones should abandon them and move to agro-forestry zones where they would be given some lands for which they would pay annual fees, as also the farmers who already had their farms in these zones for forest land occupation.

Immediately the decision to implement the participatory management plan was announced by the project, the local communities expressed their objection to it. A farmer said in this regard:

When PAMF started, its staff members organized meetings in our villages. At these meetings, they said the project would be implemented in our region. We asked them what they really wanted to do and they replied that they were coming 
to restore the protected forests of our region. We then asked them whether or not we would be chased away later. They told us that they would not chase us away; rather that they were coming to work together with us. That was what we agreed upon together. (Source: Farmer informant, August 2008)

Another farmer said:

When the project came first, they did not tell us what they are doing now, namely, chasing people away from the forest. They said that they would give farmers some tree seedlings to replace the trees farmers had destroyed on their farms. We would grow our crops while simultaneously planting forestry trees. When these forestry trees were big enough, we would leave these sites. Suddenly, they asked some people to destroy our plantations and crops. (Source: Farmer informant, August 2008)

These interview excerpts reveal that, according to the farmers, they did not react against the PAMF project as at the beginning of the project no threat to their farming activity was apparent in the discourses of the project representatives. So, the farmers constructed positive frames about the project because it was presented to them as only beneficial; this explains their interest in the project at that time. After the announcement of the implementation of the plan, these frames about the project changed and the locals started blaming the project, as in the following statements by some farmers:

We were living here in peace and working on our farms when PAMF came and created the conflict. If somebody has his possessions and another wants to extort him, it means creating a conflict. (Source: Farmer informant, November 2007)

Another farmer added:

We don't agree with the way PAMF manages our forests because they want us to leave our farms. (Source: Farmer informant, November 2007)

These excerpts show that the farmers considered the implementation of the participatory management plan-which implied that some of them would lose their farms-.as a way of expropriating their farms. They saw this decision as a threat to their identity as farmers, and this affected their frames about the project. Here, the identity of the farmers is associated with their activities or source of livelihood. These frames became negative in contrast to the positive frames they had held about the project during the establishment of the plan. The PAMF representatives confirmed this feeling experienced by the farmers and explained it as in the following testimonies:

For them [the farmers] the project will just establish the Zoning Plan and stop by the end of the last year (2006) as it is a five-year project. So then, they will go back to their initial places in the forest. It was clear in their mind that "we will help them make it and the project will finish before they implement it. They will leave and we will go back again to our places." The forest will become what it was before the project. When they realized at the end of 2006 that the project started again with the implementation of the participatory management plan, they said "we will 
never leave.” (Source: Bantè's PAMF office head, September 2008)

And another PAMF staff member continued:

After the zoning of the forest, everybody agreed that it was not acceptable for farmers to be scattered everywhere in the forest. So, they had to be concentrated in the agroforestry zones. However, at that time we did not know who had to leave the forest and who could stay. When the details of the Zoning Plan were demonstrated in the field, those who found their lands in production and protection zones of the forest, and who had to be displaced, started to complain that they didn't agree with the zoning, nor would they leave. (Source: PAMF staff member in Bantè, September 2008)

The PAMF staff members in these testimonies corroborated the idea that the local communities accepted the project at the beginning of the implementation of the plan without resistance because they did not feel their identity directly threatened by the project. Their frame shift was triggered by the imminence of the threat to their source of livelihood.

\subsubsection{The OSN Forests Case}

The implementation of the participatory management plan in the OSN forests started without trouble, in contrast to the Agoua forest case [14]. Indeed, this phase was not that different from the establishment phase because all the actors involved in the former phase remained, and the activities undertaken during the previous phase continued. One difference between the two phases was that the implementation phase started without any project to support it as the end of the NRM project coincided with the end of the establishment phase in 1999. Notwithstanding this difference, the implementation phase started quite well, as articulated by the local communities' representatives in the following utterances:

At the beginning of the participatory management plan implementation, everything went alright. At that time, when the FRs wanted to go anywhere in the forest, we went together. They never entered the forest without some member of the VAFM board. When they caught illegal users in the forest, before deciding anything they called us. When they fined them, before going to make the payment in the state's bank account, we used to collect what belonged to VAFM. They even gave us their permission to enter and carry out surveillances in the forests when they were away. If we caught illegal users, they only asked us to wait for them before deciding on the measures to be taken. (Source: Focus group discussion with Bétérou VAFM board members, January 2009)

The facilitator from the NGO involved in the establishment of the participatory management plan confirmed this view and said:

The early period of the participatory management plan's implementation was great. We worked with both FRs and VAFM without any problem. It was because all those present at that point in time were trained together by the NRM project. We had worked together with them during the NRM project period. (Source: APIC facilitator at Bétérou village, February 2009) 
These statements show that, initially, the implementation phase proceeded without any complaint from the stakeholders. Both the FRs and VAFM members pointed out that they had known each other during the first phase and carried out the activities in the participatory management plan together, and that this was the source of the relative success. However, a few years later, new FRs were appointed in the villages surrounding the OSN forests. In fact, the forest department developed the rotation system to avoid letting FRs spend a long time in any one place because they might develop corrupt and collusive behaviour.

Conflict about the implementation of the participatory management plan for the OSN forests started when the new FRs arrived. The new FRs and the local communities disagreed on roles and responsibility sharing in carrying out the different activities and started accusing each other of misconduct. For the local communities:

The new FRs, when they came, had chosen to work with villagers who were not members of the VAFM board. Even when we complained to the higher level of the forest department hierarchy they said nothing. What could we do? As they are the FRs so they can manage the forests alone. When everything finishes in the forests, we will all stay quiet. (Source: Focus group discussion with Bétérou VAFM board members, January 2009)

They also argued:

The FRs started considering us like their trackers or their workmen, and I told them that we are not like that. I told them that we are members of an organization with which they should work as partners. We then decided if it is like that they should manage the forest alone and we will just watch them. (Source: Focus group discussion with Bétérou VAFM board members, January 2009)

In these interview excerpts, the representatives of the local communities expressed their opposition to the new FRs who wanted to change their status co-constructed with the former FRs. Instead of considering them as partners like the former FRs, the new FRs wanted the VAFM members to serve them. The VAFM members in fact opposed changing their identity co-constructed with the former FRs during the establishment phase and which conferred on them some roles and responsibilities; but the FRs rangers believed that the conflict was caused by their behaviour in stopping the VAFM members from exceeding their remit. The following statement by an FR confirms this feeling of the new FRs:

The VAFM members who should work with the FRs transformed themselves into FRs. In the villages you could notice VAFM members were called "Bâ-Forêt" [FR in local language]. When a logger came into the village, he was directly sent to the VAFM members who authorized him to log trees in the forests without referring to us. They even carry out surveillances and receive taxes from illegal loggers and herders without informing us, but this does not come within their remit. (Source: Head of N'Dali Municipality forest department office, February 2009) 
According to the FRs in this statement, the VAFM members embodied the FRs' identity, which allowed them to take some actions that they should not. So, they tried to stop them but the VAFM members considered this unacceptable.

The statements above show that both the FRs and the VAFM members were fighting for their new identity. The VAFM members believed that the new FRs did not want to honour their identity built with the former FRs, which conferred on them some roles and responsibilities. The new FRs as well were struggling for their identity, which they also considered threatened by the VAFM members who were using it. In this case, the identities of the stakeholders were more characterized by their roles and responsibilities in the implementation of the plan. The conflict emerged because each stakeholder felt their new identity threatened by the other.

\subsubsection{The PNP Case}

The implementation of the PNP participatory management plan started with much enthusiasm on the stakeholders' part, like in the OSN case [15]. Both the park direction and the local communities were satisfied because they acknowledged that they were all gaining from the process. The director of the park stated in this respect:

I can say that, for at least five years, we saw the impacts of the involvement of local communities because of the positive improvement in wildlife, which was perceptible. At the same time, we noticed an improvement in our relationship with them. (Source: Director of PNP, January 2010)

This feeling of the park director was confirmed by the local communities, as in this testimony by one of them during a focus group discussion:

When we poach and kill an animal, we use only some of the meat and leave the rest in the park. This is not significant compared to what we receive from the park direction for working with it. We build schools, health centres, pay teachers and nurses with this money, which is good for us and for our children. Also nowadays it is more and more difficult to hunt without anybody else in the village noticing and telling the VAFM members or the park direction. (Source: Focus group discussion with local communities, November 2009)

These interview excerpts show that the local communities considered that working with the park direction was better than continuing poaching. The park direction noticed this change in local communities' behaviour through their collaboration in fighting against poaching and the results obtained.

However, the park director's statement also points to the fact that this situation lasted for only five years. Indeed, after five years, the park direction noticed an increase in poaching in the park and accused the eco-guards of being responsible for it. The park director posited it in the following statement:

The eco-guards started behaving like in the public sector. You may know what is happening there. It is that once you become an agent of the public sector, your job is secure for 30 years. Whether you work or not, you will get your salary at the end 
of each month until you retire and start getting your retirement allowances. (Source: Director of PNP, January 2010)

He explained this behaviour by the eco-guards, saying:

In the management of the park, we made a mistake in putting in place a remuneration system that is not linked to results; an automatic remuneration like in the public sector. (Source: Director of PNP, January 2010)

The park director continued, arguing:

Because they thought they acquired a permanent job situation, they wanted to gain more by any means and even by using their position as eco-guards, someone who should protect the park, to be in cahoots with the poachers. (Source: Director of PNP, January 2010)

These statements show that, for the park direction, poaching started to increase in the park because the eco-guards became aware that their status had changed as their job was secure. So, they did not need to work to get their salary paid and even conspired with the poachers, according to the park direction. The park direction believed that it was the development of this new identity by the eco-guards that explained their strange behaviour. He was supported by the park direction's technical advisor, who argued that:

The eco-guards developed a "spoiled child" complex. As they had often succeeded in the past in getting some benefits through claiming and disobedience, finally it became a habit for them. They were asking for more and more benefits, threatening to stop working if they did not get satisfaction. As there were no more benefits to give them, they started working less and less. In my view, this could lead to the disappearance of the eco-guards' corps. (Source: PNP technical advisor, February 2010)

This testimony of the technical advisor reveals that the park direction considered that the eco-guards were exaggerating their claims due to their status and started thinking about measures to be taken against them.

Although the eco-guards acknowledged the increase in poaching in the park due to the decrease in their motivation over time, to explain their behaviour they evoked the particularity of their job compared to how they were treated by the park direction. They expressed it in the following interview excerpts:

We have been doing this job for almost 10 years. Nobody could be active in this job after 10 years like he was at the beginning. In a few years, we will become unable to perform this job. Some young eco-guards should be recruited to refresh the corps. (Source: Eco-guard informant, December 2009)

Another eco-guard added:

The important problem is our career, which is wrongly managed by the park direction. As our job is physically demanding, we should be strongly motivated to maintain our performance but the park direction did not do so. From the time we 
started, we got an annual salary raise until 2006. But since then, we have been getting the same salary. We did not get any promotion and in five years some of us will not be able to go on surveillance because they will become useless... it seems like we are like bananas that the park direction will eat the flesh and then throw away the peels later. (Source: Eco-guard informant, January 2010)

These interview excerpts show that the eco-guards explained their behaviour as a response to the way the park direction considered and treated their corps of eco-guards. According to them, they were treated without considering the difficult aspect of their job and its consequences on their life. They felt their future in danger and preferred to take action as soon as possible. The eco-guards considered that their rights and the promises made to their corps had not been honoured by the park direction.

The conflict in the management of the PNP was born from the mutual accusations of the park direction and the eco-guards about the root cause of the increase in poaching in the park. The park direction considered that the eco-guards had lost their motivation because they had become overconfident as their job was secure, whereas the eco-guards explained their loss of motivation as a result of the park direction not fulfilling its obligations towards them. The park direction pointed to the eco-guards' identity shift as the explanation for their behaviour, whereas the eco-guards considered their behaviour as a response to the threat to their eco-guard identity.

The cases studied proved that several features contributed to the salience of social identities and highlighted some of them. Each of the cases informed us about a feature of social identity that may have led to conflict when threatened in a multi-stakeholder collaboration such as the participatory management of natural resources. In the Agoua forest conflict, the social identity feature that was made salient was the source of livelihood. Thus, people who shared the same source of livelihood considered themselves as having the same social identity when this source of livelihood was threatened. A similar situation was revealed in the case of the conflict in the management of the OSN forests where people sharing the same roles and responsibilities claimed a similar social identity and reacted when it was threatened by those they considered as outsiders-the new FRs. In the case of the conflict in the PNP management, social identity was made salient through the eco-guards claiming rights and promises when they felt these rights and promises threatened by the park direction. In all three cases, the conflict was an identity conflict as groups polarized because their identities were threatened.

In the three cases, the forest department representatives took some measures to manage the situation. However, in all three, these measures led to escalation of the conflict.

\subsection{Conflict Management and Escalation}

The conflicts in the three cases studied evolved differently. In each case, the parties involved undertook some actions to cope with the situation. Different strategies were used by the parties according to the nature of the conflict they were facing. However, in all three cases, despite the management strategies deployed by the officials to resolve the conflicts, they escalated. 


\subsubsection{The Agoua Forest Case}

The conflict became open in the case of the restoration of the Agoua forest when the farmers violently expressed their opposition to the decision of the PAMF project to implement the zoning plan at a meeting held by the forest department representatives, the PAMF staff members, the municipality staff members, and the local communities in Bantè municipality where the conflict was unfolding. At the meeting, the local communities contested their involvement in the formulation of the zoning plan. They also denied the existence of enough land in the agro-forestry zones for the farmers who had to abandon their farms in the protection and production zones. For them, the lands designated by the forest department already belonged to farmers who would not agree to others settling there.

Because they did not get satisfaction and the project destroyed a cashew plantation, the farmers wrote a letter to the president requesting his personal involvement in the management of the conflict and also organized a march, broadcast on national television, to publicize their protest against the project's decision. They informed the president that the PAMF project was hindering their effort to contribute to increasing agricultural production. These actions were meant to create a group effect amongst farmers and also to get support from others such as the president and national opinion. These actions paid off, as both farmers who were affected and others who were not directly affected by the conflict participated in the march, and the president reacted by sending the minister of the environment and nature conservation, and later an inter-ministerial commission, to solve the problem. These actions put the PAMF under pressure because it was warned by the president to solve the problem as fast as possible and also because the project was coming to an end. Thus, the forest department organized a meeting to resolve the conflict. The main outcomes of the meeting were that the farmers were allowed to harvest cashew plantations that were more than five years old for eight more years, after which they would be destroyed; the annual fees for forest land occupation were reduced; and a promise was made to the farmers to ask the government to compensate the departing farmers.

However, these decisions escalated the conflict. Although the meeting ended with a report, which was signed by all the participants including the farmers' representatives, the farmers decided henceforth not to abandon their farms in the forest under any conditions. After the meeting, the farmers' representatives argued in this respect with the researcher:

Researcher: What do you think about the outcomes of the meeting?

Farmers' representative 1: All the solutions adopted there where proposed by them. They did not accept any of our propositions. We asked them to compensate us and they said that they could not ask the president to give us compensation as many other villages are in the same situation. If they compensate us, they will have to do the same for these other villages. We told them that we were not asking for compensation for the land we are leaving but for our plantations, as we would need a lot of funding to start other ones. Many of us are old and weak and do not have the strength necessary to create a new plantation without funding. 
Researcher: But why did you sign the report of the meeting?

Farmers' representative 1: We just accepted keeping in mind that we will not leave unless the state pays us every year what we get from our cashew plantations. We know that it cannot do that, so we are sure that we will never leave. Even when we told this to the farmers, most of them answered that they don't want any kind of compensation but only to let them continue harvesting their cashew plantations. Farmers' representative 2: First of all, they invited us to a city far from the place where the problem is taking place, and at the end of the meeting they threatened us by saying that those parties who will not respect the agreements will be taken to court. (Source: Interview with farmers' representatives, November 2007)

This interview excerpt displays that, whereas the project managers believed that the conflict was resolved as the farmers' representatives signed the final report of the meeting, the farmers did not agree with the project. By saying "... they [the farmers] don't want any kind of compensation but only to let them continue harvesting their cashew plantations," the farmers meant that they were not ready to accept any compromise if it meant that they had to leave their farms.

The reactions of the farmers' representatives and their peers show that they considered the solutions adopted by the meeting as threatening their identity. Talking constantly in terms of "we" versus "they", shows that identities have been shifted again to the initial stage. The farmers' representatives expressed their feeling that the decisions were made at the meeting by threatening them. Their peers considered that these decisions of the PAMF were still threatening their livelihood.

Thus, instead of resolving the conflict, the outcomes of the meeting escalated the conflict as it pushed the farmers to reject any compensation that would be given to them to leave their farms. The project ended in an impasse as the plan was not implemented by the time the project ended in June 2008 .

\subsubsection{The OSN Forests Case}

In the case of the conflict in the implementation of the OSN participatory management plan, no measure was immediately taken by the forest department in this regard although the VAFM board members complained about not being involved in the implementation of the activities foreseen in the plan. Thus, the activities were carried out by each of the parties separately at the expense of the forest users such as loggers and herders who grazed their cattle in these forests. Indeed, these stakeholders complained that they were often obliged to pay many times the taxes for any activity they carried out in the forests to either the FRs or the VAFM board members, or even both, and sometimes to other villagers who presented themselves as members of the VAFM board or sent by the FRs.

The management of the conflict started only after the FALM programme was launched in 2003 to support the implementation of the plan. The first measure undertaken by this programme to resolve the conflict was to take unilaterally the decision to stop logging in the OSN forests, the main activity in the implementation of the participatory management plan, because it was not being carried out as it should be according 
to its managers. This measure was justified by the head of Borgou forest department who said:

Unfortunately, the money collected by the members of the VAFM boards is misappropriated. An audit of the management of the OSN's VAFM from the introduction of co-management until now showed that up to $80 \%$ of the money collected has been misappropriated and the board members are not bothered. They know their job perfectly, but it is a lack of patriotism that has led to bad management of the resources. (Source: Head of Borgou's forest department office, February 2009)

He meant by this statement that the forest department stopped logging because the VAFM were misusing the money they collected in organizing it. However, instead of solving the problem, this measure escalated the conflict. As far as the local communities were concerned, the forest department took this measure to be able to organize logging alone as, although this measure was enacted, the FRs continued to send their sawyers into the forests to log, as in the following utterance:

In the past, the loggers were allowed to get a licence and log only with hand saws and not the motor chain-saws. During this period, when the licensed loggers were in the forest and heard the motor chain-saw sound, they informed us because they knew that motor chain-sawyers were illegal. We informed the FRs and they were caught. So the legal loggers helped us arrest the illegal loggers because they were jealous. Suddenly in 2005, logging was forbidden by the forest department even for those who had a licence. They did it to be free to send their own sawyers into the forest; since then, illegal logging has increased anarchically. (Source: Focus group discussion with VAFM board members of Beterou, January 2009)

The VAFM members also interpreted this measure as a way of pushing them out of the process, as in this statement:

It seems like the forest department proclaimed publicly that local communities are managing the forests through the VAFM, while FRs are illegally exploiting forest resources. Then, they would be able to say later that it is local communities who are responsible of the degradation of the forests and conclude that the sustainable management of the forests using a participatory approach failed. (Source: Focus group discussion with Beterou VAFM board members, January 2009)

This testimony of the VAFM members shows that, as far as they were concerned, the intention of the new FRs in marginalizing them in the process, and of the forest department in stopping logging, was part of a hidden agenda of the forest department that was trying to stop the participatory process itself and accused them of being responsible. For the VAFM members, it was a plot against them prepared by the forest department. So, instead of rebuilding between the new FRs and the VAFM members the cohesive relationship that had existed between the former FRs and VAFM members, the FALM programme escalated the conflict that brought them into opposition through its 
corrective measure, as the VAFM members considered it as a threat to their identity in the participatory process as a whole. This measure created more distance between the two parties who continued working separately and often undermined each other's actions.

\subsubsection{The PNP Case}

To manage conflict in the PNP, the park direction decided in August 2009, instead of negotiating with the eco-guards to look for ways of improving their performance, to negotiate with the poachers and involve them in the surveillance of the park. The poachers were henceforth called local professional hunters (LPH) (Chasseurs Professionels Locaux) by the park direction, and they were told to form their own organization. Since then, they have been going on surveillance in the same teams as the eco-guards. The park direction justified its decision in the following statement by the park director:

We encourage the combination of actors for the surveillances to avoid collusion and corruption. Because when you alone hold the power like it was with the eco-guards in the past, collusions start. But now that the LPHs-with whom the eco-guards used to collude-are also involved in the surveillances, it complicates things for the eco-guards. We are even getting some good results. The LPHs started reporting the eco-guards' behaviours to us. They told us that sometimes the eco-guards don't want to go far into the park for surveillance. The LPHs want to show that they are trustworthy. (Source: Director of PNP, January 2010)

This piece of talk shows that the park direction distrusted the eco-guards and included the LPHs to counterbalance the impact of the eco-guards on park surveillance. For the park direction, the presence of the LPHs in the surveillance teams was a guarantee that the behaviour of the eco-guards would change. However, the eco-guards complained about this decision, claiming that they did not trust the reconverted poachers and even feared them. They expressed it in the following statements:

Nothing proves to us that the LPHs are fully converted. Giving them guns and allowing them to go on surveillance is a danger as there is nothing to say that they won't start their former behaviour again once they know all our surveillance strategies. (Source: Eco-guard informant, January 2010)

And another eco-guard added:

The park direction is asking us to go on surveillance with the LPHs who we had tracked for many years. We found it difficult to work with our enemies as it is an opportunity that the park direction is giving them to pay back what we did to them. (Source: Eco-guard informant, January 2010)

The eco-guards in the statements above rather considered the involvement of the LPHs as a threat to them because they were skeptical about the hunters' change of heart and also because of their former relationship with them. The decision of the park direction also increased the eco-guards' distrust of the park direction about its willingness to 
improve their working conditions. An eco-guard stated in that sense:

The eco-guards are frustrated as the park direction still owes them four years of bonuses, saying that there are not enough resources. But where do the resources that are used to pay the LPHs come from? (Source: Eco-guard informant, December 2009)

These statements show that the eco-guards considered their identity threatened by the decision of the park direction to involve the poachers in the management of the PNP. Even though the LPHs were also part of the local communities, the eco-guards did not agree with their involvement in the surveillance of the park as they saw their inclusion as a way of reducing their importance in the process and as reflecting the unwillingness of the park direction to meet their needs. Thus, this decision by the park direction escalated the conflict as the eco-guards perceived it as a threat to their identity, and their distrust of the park direction increased. As in the OSN forests case, the park direction in this case took the decision to involve the LPHs without involving the eco-guards in its decision-making process. This decision was taken by the park direction because it believed that it was the best way to counterbalance the influence of the eco-guards and fight against poaching.

The outbreak of conflict in the management of the protected areas triggered each party's reaction. In the three cases, the conflicts escalated because the features that made salient the social identities of the parties were not addressed properly in the decisions made to resolve the conflicts. Rather, the actions undertaken to manage the conflicts escalated the conflicts as they were perceived as threatening the identities of the local communities in the different cases.

\section{Discussion and Conclusions}

Participatory management of natural resources often involves different stakeholder groups with different social identities [16]. As the mere social categorization of stakeholders is an inevitable source of conflict, several strategies are used to deal with differences in social identity in negotiation [16] [33] [35]. We revealed in this study that different negotiation models were adopted in the participatory management of the protected areas in Benin. The models adopted by the PAMF and the NRM project, respectively in the Agoua forest case and the OSN forests case, were close to the dualidentity model, whereas in the PNP case the model adopted by the park direction was close to the recategorization model. However, neither the recategorization nor the dualidentity model proposed for intergroup negotiation represents a panacea to deal with identity conflicts. The adoption of both models in different intergroup negotiation processes did not prevent conflicts from emerging in the management of these protected areas in Benin. In both models, conflict emerged because the different identities of the subgroups of involved stakeholders became more salient than the superordinate identity supposed to encompass all the members of the subgroups, which was downplayed. The salience of the subgroups' identities was triggered by contextual factors that were framed as threats by the members of these subgroups [16] [24] [25] [39]. The de- 
cision of the PAMF to implement the participatory management plan was framed by the farmers in the Agoua forest as a threat to their livelihood and triggered the salience of their identity. The VAFM members in the OSN forests interpreted the behaviour of the new FRs when they arrived as a threat to the roles and responsibilities that they had co-constructed with the former FRs, and their identity became salient. In the case of the PNP, the identity of the eco-guards became salient when they framed the behaviour of the park direction as a threat to their rights and promises to them because the park direction was not honouring these.

The study also shows that new identity creation is a potential source of identity conflict as it offers room for new categorizations and claims. In the OSN and PNP cases, new identities were created-VAFM members in the case of the OSN and eco-guards and LPHs in the case of the PNP. Conflicts emerged in these cases as these new identities became salient when their members felt that their identities were threatened their roles and responsibilities in the case of the VAFM members, and their rights and promises in the case of the eco-guards.

When the identity of a stakeholder group becomes salient, it affects the behaviour of its members and leads to conflict [16] [25] [34]. The stakeholders undertake collective actions to react against the threat to their identity. These actions result in the strengthening of the cohesion among the group members, coalitions building, and fighting against the threat. The farmers in the Agoua forest management case organized a march and wrote to the president; the VAFM board members decided to withdraw from the process and continued carrying out activities on their own; and the eco-guards became demotivated, and this significantly reduced their spirit in carrying out surveillance in the park-an occurrence that was noticeable in the increase in poaching.

When conflict emerges, the different stakeholders involved undertake actions to deal with the situation. Nevertheless, conflicts often escalate. We found that the escalation of the identity conflicts in the management of the protected areas in Benin arose as a result of unilateral decision-making and the outcomes of it as framed by the stakeholders. Although a participatory approach was ostensibly used in the management of these protected areas, the perception was that a top-down approach had been taken in making the decisions that were supposed to resolve the conflicts. Farmers' representatives complained that none of their propositions was accepted and that they had been forced to accept the propositions made by the project at the meeting to resolve the Agoua forest conflict. The conflict escalated in the OSN forests case when the decision to stop logging was made by the FALM programme and the VAFM members were informed. In the case of the PNP, the conflict escalated when the park direction decided to involved the LPHs and informed the eco-guards. In the three cases, the decisions were framed by the local communities as a threat to their identity and thus they adopted a harsher attitude.

This study shows that the salience of identities is dynamic and relates to the emergence and escalation of conflict in a negotiation process (see Table 2). This dynamic is triggered by the framing of contextual factors that determine its intensity. When stake 
Table 2. Dynamic of identities and conflict emergence and escalation in the management of protected areas in Benin.

Before
Pasticipatory management

Acronyms: PAMF: Project of the Management of the Wari-Waro, Monts Kouffè and Agoua Forest Massifs. LC: Local Community; FR: Forest Ranger; PD: Park Direction; EG: Eco-Guard; LPH: Local Professional Hunter; ${ }^{\star}$ The distance between the groups shows the intensity of the conflict.

holders frame some decisions and actions as threatening their identity, this triggers the salience of their identity and leads to conflict. Thus, dealing with social identity in negotiations is a continuous and permanent process. How the stakeholders frame the decisions and actions in the negotiation process needs to be continuously checked and the negotiation model should be redesigned accordingly. This means that stakeholders must continuously listen and communicate.

\section{References}

[1] Buckles, D. and Rusnak, G. (1999) Cultivating Peace: Conflict and Collaboration in Natural Resource Management (Ottawa). In: Buckles, D., Ed., Cultivating Peace: Conflict and Collaboration in Natural Resource Management, World Bank Institute, Washington DC, 1-10.

[2] Castro, A.P. and Nielson, E. (2003) Indigenous People and Co-Management: Implications for Conflict Management. Environmental Science \& Policy, 4, 229-239. https://doi.org/10.1016/S1462-9011(01)00022-3

[3] Hares, M. (2009) Forest Conflict in Thailand: Northern Minorities in Focus. Environmental Management, 43, 381-395. https://doi.org/10.1007/s00267-008-9239-7

[4] Mola-Yudego, B. and Gritten, D. (2010) Determining Forest Conflict Hotspots According to Academic and Environmental Groups. Forest Policy and Economics, 12, 575-580. https://doi.org/10.1016/j.forpol.2010.07.004

[5] Hellström, E. (2001) Conflict Cultures: Qualitative Comparative Analysis of Environmental Conflicts in Forestry. Silva Fennica Monographs, 2, 2-84.

[6] Tyler, S.R. (1999) Policy Implication of Natural Resource Conflict Management. In: Buckles, D., Ed., Cultivating Peace: Conflict and Collaboration in Natural Resource Management, World Bank Institute, Washington DC, 264-280.

[7] Smith, D. (1997) Language and Discourse in Conflict and Conflict Resolution. Current Is- 
sues in Language and Society, 4, 190-214. https://doi.org/10.1080/13520529709615498

[8] Desloges, C. and Gauthier, M. (1997) Community Forestry and Forest Resource Conflicts: An Overview. Proceeding of the 14th World Forestry Congress, Antalya, 13-22 October 1997.

[9] Yasmi, Y., Guernier, J. and Colfer, C.J.P. (2009) Positive and Negative Aspects of Forestry Conflict: Lessons from a Decentralized Forest Management in Indonesia. International Forestry Review, 11, 98-110. https://doi.org/10.1505/ifor.11.1.98

[10] El-Hadj Issa, A. (2001) Bilan de la mise en œuvre de plan d'aménagement des forêts classées de Tchaourou Toui Kilibo. Proceeding of the Ile Séminaire International sur Paménagement intégré des forêts naturelles des zones tropicales sèches en Afrique de P Ouest, Parakou, 25-29 June 2001, 232-244.

[11] Tchiwanou, M. (2001) Bilan de la mise en œuvre de plan d'aménagement des forêts classées de Tchaourou Toui Kilibo. Proceeding of the IIe Séminaire International sur Paménagement intégré des forêts naturelles des zones tropicales sèches en Afrique de P Ouest, Parakou, 25-29 June 2001, 132-139.

[12] Zoundoh, L. (2001) Bilan de cogestion des forêts classées de Sota, de Goungoun et de Goroubi avec les populations riveraines au Nord Bénin: Cas du projet Aménagement Participatif des Forêts Naturelles et Reboisement Villageois pour la Réduction de Carbone. Proceeding of the IIe Séminaire International sur Paménagement intégré des forêts naturelles des zones tropicales sèches en Afrique de l Ouest, Parakou, 25-29 June 2001, 275289.

[13] Idrissou, L., Paassen, A.V., Aarts, N. and Leeuwis, C. (2011) The Discursive Construction of Conflict in Participatory Forest Management: The Case of Agoua Forest Restoration in Benin. Conservation and Society, 9, 119-131. https://doi.org/10.4103/0972-4923.83722

[14] Idrissou, L., Aarts, N., Paassen, A.V. and Leeuwis, C. (2011) From Cohesion to Conflict in Participatory Forests Management: The Case of Ouémé Supérieur and N’Dali (OSN) Forests Management. Forest Policy and Economics, 13, 525-534.

https://doi.org/10.1016/j.forpol.2011.06.001

[15] Idrissou, L., Aarts, N., van Paassen, A., Vodouhè, S. and Leeuwis, C. (2013) Trust and Hidden Conflict in Participatory Natural Resources Management: The Case of the Pendjari National Park (PNP) in Benin. Forest Policy and Economics, 27, 525-534.

https://doi.org/10.1016/j.forpol.2012.11.005

[16] Haslam, S.A. (2001) Intergroup Negotiation and Conflict Management. In: Haslam, S.A., Ed., Psychology in Organizations: The Social Identity Approach, Sage Publications, Thousand Oaks, 179-206.

[17] Hjortso, C.N. (2004) Enhancing Public Participation in Natural Resource Management Using Soft OR: An Application of Strategic Option Development and Analysis in Tactical Forest Planning. European Journal of Operational Research, 152, 667-683. https://doi.org/10.1016/S0377-2217(03)00065-1

[18] De Jong, W., Ruiz, S. and Becker, M. (2006) Conflicts and Communal Forest Management in Northern Bolivia. Forest Policy and Economics, 8, 447-457. https://doi.org/10.1016/j.forpol.2005.08.011

[19] Götmark, F., (2009) Conflicts in Conservation: Woodland Key Habitats, Authorities and Private Forest Owners in Sweden. Scandinavian Journal of Forest Research, 24, 504-514. https://doi.org/10.1080/02827580903363545

[20] Macias, T. (2008) Conflict over Forest Resources in Northern New Mexico: Rethinking Cultural Activism as a Strategy for Environmental Justice. Social Science Journal, 45, 61-75. https://doi.org/10.1016/j.soscij.2007.12.006 
[21] Bergami, M. and Bagozzi, R.P. (2000) Self-Categorization, Affective Commitment and Group Self-Esteem as Distinct Aspects of Social Identity in the Organization. British Journal of Social Psychology, 39, 555-577. https://doi.org/10.1348/014466600164633

[22] Aspinall, E. (2007) The Construction of Grievance: Natural Resources and Identity in a Separatist Conflict. Journal of Conflict Resolution, 51, 950-972. https://doi.org/10.1177/0022002707307120

[23] Assal, M.A.M. (2006) Sudan: Identity and Conflict over Natural Resources. Development, 49, 101-105. https://doi.org/10.1057/palgrave.development.1100284

[24] Dalton, M. and Chrobot-Mason, D. (2007) A Theoretical Exploration of Manager and Employee Social Identity, Cultural Values and Identity Conflict Management. International Journal of Cross Cultural Management, 7, 169-183.

https://doi.org/10.1177/1470595807079382

[25] Korostelina, K. (2007) The System of Social Identities in Tajikistan: Early Warning and Conflict Prevention. Communist and Post-Communist Studies, 40, 223-238. https://doi.org/10.1016/j.postcomstud.2007.03.001

[26] Livingstone, A. and Haslam, S.A. (2008) The Importance of Social Identity Content in a Setting of Chronic Social Conflict: Understanding Intergroup Relations in Northern Ireland. British Journal of Social Psychology, 47, 1-21.

https://doi.org/10.1348/014466607X200419

[27] Chapman, J. (2006) Anxiety and Defective Decision Making: An Elaboration of the Groupthink Model. Management Decision, 44, 1391-1404.

https://doi.org/10.1108/00251740610715713

[28] Flippen, A.R. (1999) Understanding Groupthink from a Self-Regulatory Perspective. Small Group Research, 30, 139-165. https://doi.org/10.1177/104649649903000201

[29] Henningsen, D.D., Henningsen, M.L.M., Eden, J. and Cruz, M.G. (2006) Examining the Symptoms of Groupthink and Retrospective Sensemaking. Small Group Research, 37, 3664. https://doi.org/10.1177/1046496405281772

[30] Stets, J.E. and Burke, P.J. (2000) Identity Theory and Social Identity Theory. Social Psychology Quarterly, 63, 224-237. https://doi.org/10.2307/2695870

[31] Zhou, X. and Mori, H. (2011) National Institutional Response to Climate Change and Stakeholder Participation: A Comparative Study for Asia. International Environmental Agreements. Politics, Law and Economics, 11, 297-319. https://doi.org/10.1007/s10784-010-9127-5

[32] Tajfel, H., Billig, M.G., Bundy, R.P. and Flament, C. (1971) Social Categorization and Intergroup Behaviour. European Journal of Social Psychology, 1, 149-178. https://doi.org/10.1002/ejsp.2420010202

[33] Tzeng, O.C.S. and Jackson, J.W. (1994) Effects of Contact, Conflict, and Social Identity on Interethnic Group Hostilities. International Journal of Intercultural Relations, 18, 259-276. https://doi.org/10.1016/0147-1767(94)90031-0

[34] Hogg, M.A. and Reid, S.A. (2006) Social Identity, Self-Categorization, and the Communication of Group Norms. Communication Theory, 16, 7-30. https://doi.org/10.1111/j.1468-2885.2006.00003.x

[35] Tajfel, H. (1972) La catégorisation sociale. In: Moscovici, S., Ed., Introduction à la psychologie sociale, Vol. 1, Larousse, Paris, 272-302.

[36] Hogg, M.A. and Terry, D.J. (2000) Social Identity and Self-Categorization Processes in Organizational Contexts. The Academy of Management Review, 25, 121-140.

[37] Ashforth, B.E. and Mael, F. (1989) Social Identity Theory and the Organization. The 
Academy of Management Review, 14, 20-39.

[38] Cohen, A. and Caspary, L. (2010) Individual Values, Organizational Commitment, and Participation in a Change: Israeli Teachers' Approach to an Optional Educational Reform. Journal of Business and Psychology, 26, 385-396. https://doi.org/10.1007/s10869-010-9186-1

[39] Fischer, P., Haslam, S.A. and Smith, L. (2010) "If You Wrong Us, Shall We Not Revenge?" Social Identity Salience Moderates Support for Retaliation in Response to Collective Threat. Group Dynamics. Theory, Research, and Practice, 14, 143-150. https://doi.org/10.1037/a0017970

[40] Van Knippenberg, D., Van Knippenberg, B., Monden, L. and De Lima, F. (2002) Organizational Identification after a Merger: A Social Identity Perspective. British Journal of Social Psychology, 41, 233-252. https://doi.org/10.1348/014466602760060228

[41] Phinney, J.S. (1991) Ethnic Identity and Self-Esteem: A Review and Integration. Hispanic Journal of Behavioral Sciences, 13, 193-208. https://doi.org/10.1177/07399863910132005

[42] Gaertner, S.L., Mann, J., Murrell, A. and Dovidio, J.F. (1989) Reducing Intergroup Bias: The Benefits of Recategorization. Journal of Personality and Social Psychology, 57, 239-249. https://doi.org/10.1037/0022-3514.57.2.239

[43] Hewstone, M., Rubin, M. and Willis, H. (2002) Intergroup Bias. Annual Review of Psychology, 53, 575-604. https://doi.org/10.1146/annurev.psych.53.100901.135109

[44] Gaertner, S.L., Rust, M.C., Dovidio, J.F., Bachman, B.A. and Anastasio, P.A. (1996) The Contact Hypothesis: The Role of a Common Ingroup Identity on Reducing Intergroup Bias among Minority Group Members. In: Nye, J. and Brower, A., Eds., What's Social about Social Cognition? Research on Socially Shared Cognition in Small Groups, Sage, Newbury Park, 230-260. https://doi.org/10.4135/9781483327648.n10

[45] Akpado, L. (1996) Etude sur la valorisation et le développement du bois d'œuvre dans le cadre de l'Aménagement des Massifs Forestiers des Monts-Kouffé, Wari-Maro et Agoua. MDR/DFRN/PBF, Cotonou.

[46] PGRN (1999) Plan d'Aménagement Participatif des Forêts Classées de l'Ouémé Spérieur et de N'dali.

[47] Fairhurst, G.T. (2004) Textuality and Agency in Interaction Analysis. Organization, 11, 335-353. https://doi.org/10.1177/1350508404041996

[48] Jordan, B. and Henderson, A. (1995) Interaction Analysis: Foundations and Practice. Journal of the Learning Sciences, 4, 39-103. https://doi.org/10.1207/s15327809jls0401_2

[49] Arouna, O. (2006) Evaluation du plan d'aménagement participatif des forêts classées de Goun-Goun, de la Sota et de la Rôneraie de Gouroubi au Bénin: critères et indicateurs pertinents de réussite. The Colloque international GECOREV sur Gestion concertée des ressources naturelles et de Penvironnement, du local au mondial: pour un dialogue entre chercheurs, société civile et décideurs, Saint-Quentin, 26-28 June 2006, 1-29.

[50] MDR and PGFTR (1999) Audit Institutionnel du Secteur Forestier. Diagnostic du Secteur Forestier. MDR (Ministère du Développement Rural)/PGFTR (Projet Gestion des Forêts et Terroirs Riverains), Cotonou.

[51] Siebert, U. and Elwert, G. (2004) Combating Corruption and Illegal Logging in Benin, West Africa: Recommendations for Forest Sector Reform. Journal of Sustainable Forestry, 19, 239-261. https://doi.org/10.1300/J091v19n01_11 
Submit or recommend next manuscript to SCIRP and we will provide best service for you:

Accepting pre-submission inquiries through Email, Facebook, LinkedIn, Twitter, etc. A wide selection of journals (inclusive of 9 subjects, more than 200 journals)

Providing 24-hour high-quality service

User-friendly online submission system

Fair and swift peer-review system

Efficient typesetting and proofreading procedure

Display of the result of downloads and visits, as well as the number of cited articles

Maximum dissemination of your research work

Submit your manuscript at: http://papersubmission.scirp.org/

Or contact jep@scirp.org 